\title{
HOW TAXES CAN CONTRIBUTE TO THE IMPLEMENTATION OF THE PUBLIC GOVERNANCE STRATEGY? - AN ANALYSIS FOR EASTERN EUROPEAN COUNTRIES
}

\author{
Cristina Vlad \\ The Academy of Economic Studies, Bucharest, Romania \\ cristina.vlad8@gmail.com \\ Birol Ibadula \\ The Academy of Economic Studies, Bucharest, Romania, \\ birol_ibadula@yahoo.com \\ Professor Petre Brezeanu \\ Faculty of Finance, Insurance, Banking and Stock Exchange, \\ The Academy of Economic Studies, Bucharest, Romania, \\ brezeanupetre@yahoo.com
}

(Received April 2016; Accepted June 2016)

\begin{abstract}
The paper begins with a short literature review regarding the public governance concept in the EU approach and its methods for establishing a common way to manage different situations for all member states; we discovered that the problems they confront with have to do with good governance and qualitative public administration. In the second part, we developed an econometric model for three Eastern European countries and we found a strong correlation between the total revenues from taxes and social contributions and total gross debt in 2002-2014 period. We ended the paper by emphasizing the conclusions obtained.
\end{abstract}

Key words: Governance, Fiscal policy, Public debt

JEL Classification: H20, H63, H10

\section{INTRODUCTION}

When we are attempting to analyze how fiscality in a country can contribute to a better governance, so that this country to achive its economic performance, the first problem that emerges is the meaning of good public governance. How can this be defined? What can lead to a good governance? Has it been discovered a succesfull recipe that can ensure a good public governance? For sure not. In 2002 the World Bank defined the governance as 'The ability of the state to provide those institutions that support growth and poverty reduction-often referred to as good governance-is essential to development' (Pere, E. 2015).

Good governance plays an important role in implementing successful economic policies. It provides reliability, transparency and predictability in policymaking, efficiency and equity in access to government services and resources, as well as

18 Studia Universitatis "Vasile Goldis" Arad. Economics Series Vol 26 Issue 3/2016 
Vlad C., Ibadula B., Brezeanu P. (2016)

How taxes can contribute to the implementation of the public governance strategy? - An analysis for Eastern European Countries

equity in civil and political rights. Governance weaknesses, in turn, can involve onerous, ineffective and predatory regulatory procedures, and corruption that discourages entrepreneurial talent and undermines economic performance (Caceres C., 2012).

There are a lot of external factors which influence the public governance so that the responsible institutions to find different levers to apply the best economical methods. All policies applied in a country, depending on the degree of development and on the priorities set are shaping the public governance. And in this article our main focus will be on fiscal policies.

What is governance? Definitions can be complex, challenging and powerful. Governance is not the synonym of government. The confusion of terms can have unfortunate consequences. A public policy issue where the importance of the matter is a problem of "governance" without which becomes respectively defined as a problem of "government. Then, if governance is not about government, what is it about? It is about how governments and other social organizations interact, how they communicate to citizens, and how decisions are taken in a complex world with different situations. Thus governance is a process whereby societies or organizations make their important decisions, define whom they involve in the process and how to solve the problems. If a process is hard to observe, students of governance tend to focus our attention on the governance system or framework upon which the process rests - that is, the procedures, agreements, conventions or policies that define who gets power, how decisions are taken, are put into practice and how accountability is rendered (Graham J. et al, 2003).

The practice of good governance makes the difference between successful democratic nations from those many states which do little for their people. Governance is the delivery of a set of critical public goods to citizens: security, political freedoms, rule of law, an enabling framework for economic performance, health, education, and so on. Where a regime fails to perform, the reason is the failure to provide reasonable quantities and qualities of essential public goods, it is a sign of poor governing (Besancon M., 2003).

To observe in these days that solutions to societal problems require the combined efforts of the public, private, and voluntary sectors is a truism. This observation may be axiomatic and how best to combine those efforts continues to be a topic of ongoing discussion and debate. The question is all the more pressing given the current global challenges facing individual societies; among them, the most listed are: climate change, failed states, economic downturns, poverty, terrorism, citizen safety and security, affordable goods and services, and immigration. Addressing these challenges, taking advantage of the opportunities they provide, and mitigating 
Vlad C., Ibadula B., Brezeanu P. (2016)

How taxes can contribute to the implementation of the public governance strategy? - An analysis for Eastern European Countries

threats calls for new organizational arrangements and commitments across sectors (government, business, and voluntary) (Brinkerhoff D. W. et al, 2011).

\section{LITERATURE REVIEW}

The existing literature presents mixed results regarding the relationship between public governance and economic development. There should be a mix of private and government decision for maximizing growth. And the fiscal policies applied play an important role in this respect.

On the basis of a game theoretic approach in the tradition of Barro and Gordon (1983) in which weak public governance is modeled as an erosion of the ability to collect revenue through regular tax channels, Huang and Wei (2006) argue that the majority of prescribed solutions to the monetary policy credibility problem are likely to fail in countries with low institutional capacity. The optimal inflation rate in such countries is actually higher than that normally required by a monetary arrangement like a fixed exchange rate or a currency board. These two authors show that some nations might fall into what they call a „poor institution trap": authorities faced with severe governance problems would no longer be willing to improve fiscal capacity and institutional quality from the moment that the cost of the reforms needed to fight corruption, exceeds a certain threshold. By making use of a similar model, Hefeker (2010) highlights the existence of a trade-off between higher institutional quality with lower inflation versus higher taxes with lower output (Faure P., 2011).

Dziemianowicz (2014) defines the fiscal governance, as coordination of fiscal policy, covered by the broadly defined concept of public governance, which was established on the basis of public sector reforms and an attempt to introduce the governance methods applicable in the private sector to the public sector. In objective meaning, fiscal governance is defined as rules, regulations and procedures that affect the way fiscal policy is planned, approved, conducted and monitored. Policy experiences show that strong fiscal governance is an important factor for fiscal performance as it can help contain the deficit bias of fiscal policy making, which was frequently observed across EU Member States over the past decades. This has also been acknowledged by the European Council which in the reform of the Stability and Growth Pact in 2005 asked EU Member States to strengthen their domestic fiscal governance through fiscal rules and institutions. This database provides details on the EU Member States' fiscal governance.

But can somebody know for sure that if the member states apply all these rules they will be able to pass crisis times in good conditions? In Benczes opinion, "the recovery from the crisis should induce countries to implement economic policies which not simply stop further deficit financing and debt accumulation, but also

20 DE GRUYTER OPEN
Studia Universitatis "Vasile Goldis" Arad. Economics Series Vol 26 Issue 3/2016 ISSN: 1584-2339; (online) ISSN: 2285 - 3065

Web: publicatii.uvvg.ro/index.php/studiaeconomia.Pages 18 - 32 
Vlad C., Ibadula B., Brezeanu P. (2016)

How taxes can contribute to the implementation of the public governance strategy? - An analysis for Eastern European Countries

restore the long-term competitiveness and sustainability of the crisis-hit countries. The already high level of income centralization does not allow advanced countries (especially the ones in the European Union) to further increase marginal tax ratios because this would endanger competitiveness of their economies on a world-wide scale. Crisis management, however, was pursued not by the lowering of taxes. Instead, governments engaged in extra public spending (Benczes I., 2011).

The connection between fiscal revenues and the public debt is also confirmed in previous studies but seems that this connection is not the same in every country or every time. Different economic cycles and different approaches can create different types of macroeconomic correlations.

Besançon (2003), examines the nature of the governance problem and the extent to which the questions have been answered. She reports on a WPF-Programorganized meeting at the Kennedy School of Government that had discussed these and other critical governance issues. Her detailed analysis describes policy makers to re-examine the criteria being readied for the Millennium Challenge Account, and those being used formally or informally by several national aid agencies. It also prepares policy makers to determine on the feasibility of creating a good method for comparing how one government performs against another (Besancon M., 2003).

Taking into consideration Governance, some questions arise: Who are the players? Who has influence? Who decides? The concept of governance may be usefully applied in some contexts - global, national, institutional and community. Understanding governance at the national level is made easier if one considers the different types of entities that occupy the social and economic landscape.

In the same time the questions are: who decides and in what capacity? The concept of governance may be applied to any form of collective action. Governance is about the more strategic aspects of steering: the larger decisions about roles and direction (Graham J. et al, 2003).

\section{PUBLIC GOVERNANCE IN THE EUROPEAN UNION}

The economic and financial crisis of 2007/2009 has posed unexpected challenges at both global and regional level. Besides the US, the EU has been the most severely hit by the current economic crisis. The financial and banking crisis on the one hand and the sovereign debt crisis on the other hand have clearly shown that without a bold, constructive and systematic change of the economic governance structure of the Union, not just the sustainability of the monetary zone but also the viability of the whole European integration process can be seriously undermined. The current crisis is, however, only a symptom, which made all those 
Vlad C., Ibadula B., Brezeanu P. (2016)

How taxes can contribute to the implementation of the public governance strategy? - An analysis for Eastern European Countries

contradictions overt that were already heavily embedded in the system (Benczs I., 2011).

One of the most important objective of the European Commission is to develop a stable business environment in all member states. It is essential that the institutions responsible for the economic and social interactions within a country to be able to fulfill a certain number of criteria. And here we refer to the absence of corruption, a workable approach to competition and procurement policy, an effective legal environment, and an independent and efficient judicial system. Moreover, strengthening institutional and administrative capacity, reducing the administrative burden and improving the quality of legislation underpins structural adjustments and fosters economic growth and employment (European Commission Report, "Promoting good governance ")

But beside the national institutions of each country, the European Union, as an organization, also has an extremly important contribution in drawing the right directions that should be followed by each member state in order to get to acheive their objectives or improve their practices. The European Union's economic governance framework aims at monitoring, preventing and correcting problematic trends in each area such as budget deficit or public debt levels, if we refer to macroeconomic indicators, which can destabilize the economic environment.

Through monitoring, the European Union follows the early detection of different problems and risks caused by unsustainable policies or activities that generate declined competitiveness, through regular analysis, forecasts, assessments of national budgets or of stability and convergence programs. Additional, the European Commission publishes two important annual reports which help to identify new risks, to monitor the improvements made by member states and to establish new objectives for the next years. These reports are The Annual Growth Survey and The Alert Mechanism Report.

In order to prevent different economic problems or to stop them before affecting other member states, European Union's governments had agreed on some particular rules to be respected by all member states so that they can ensure the quality of their economic policies. The Stability and Growth Pact or the Treaty on Stability, Coordination and Governance are official documents of EU that commit all member states under some rules, which have to be respected in order to get to a common way of development. Here we can mention for example the limit of budget deficit or of the public debt to GDP. Annually, if some of these rules and not only those we had mentioned, are not respected, those countries receive recommandation from the EU and after a period of time the problematic areas are carefully monitored. And in this way, they face the correction activity of the

22 DE GRUYTER OPEN
Studia Universitatis "Vasile Goldis" Arad. Economics Series Vol 26 Issue 3/2016 ISSN: 1584-2339; (online) ISSN: 2285 - 3065

Web: publicatii.uvvg.ro/index.php/studiaeconomia.Pages 18 - 32 
Vlad C., Ibadula B., Brezeanu P. (2016)

How taxes can contribute to the implementation of the public governance strategy? - An analysis for Eastern European Countries

European Union. Member states, have to follow a particular set of procedures and they also face the possibility of warnings and ultimately sanctions.

In the next period of time, member states are facing a challenging plan because after a strong crisis and some years when they had to adjust their policies and to recover the economic stability, now they are expected to grow. Below, in the Table 1 , we can see the classification of the member states that received country-specific recommendations in 2013 related to quality of public administration and good governance, to be implemented in 2014-2020.

Table 1. Country-Specific Recommendations (2013) related to the quality of public administration and good governance

\begin{tabular}{|c|c|c|}
\hline $\begin{array}{c}\text { Sub-sector of Country Specific } \\
\text { Recommendation }\end{array}$ & Member state & $\begin{array}{c}\text { Number of Member } \\
\text { States }\end{array}$ \\
\hline $\begin{array}{c}\text { Improving the effectiveness and } \\
\text { efficiency of the public administration }\end{array}$ & $\begin{array}{c}\text { BG, CY, CZ, ES, } \\
\text { EL, HR, IT, RO, SK }\end{array}$ & 9 \\
\hline Judiciary reform & $\begin{array}{c}\text { BG, EL, ES, HU, } \\
\text { LV, MT, RO, SI, SK }\end{array}$ & 9 \\
\hline Improve the business environment & $\begin{array}{c}\text { BG, EL, ES, HU, IT, } \\
\text { PL, RO }\end{array}$ & 7 \\
\hline Anti-corruption & BG, CZ, EL, HR, \\
\hline Public procurement & BG, IT & 7 \\
\hline $\begin{array}{c}\text { Absorption of European Structural and } \\
\text { Investment Funds }\end{array}$ & BG, RO, SK & 6 \\
\hline
\end{tabular}

Source: European Commission Report

It is very interesting to notice that after seven important years that left behind an aggressive economic crisis, (2007-2013) most of the countries with specific recommendation are facing ineffective public governance, problems in creating a judiciary reform as a part of wider reform of each country political system or a legal reform and the need to improve their business environment. Of course, business environment is a very large field to refer to and we assume that also fiscal policies applied play their important role in this. Anti-corruption, public procurement or the absorption of ESI funds are related to the previous sub-sectors with the need of improvement. 
We can also observe that the countries that received these recommendations have something in common: are Eastern European countries, with similar economic environment and level of development. Are developing or transition economies suffering from bad governance and corruption always ready to devote efforts to strengthen their institutions?

\section{THE IMPACT OF FISCALITY ON PUBLIC DEBT}

In contrast to monetary policy, the fiscal policy of the euro area countries has remained a national competence. Since it is important that countries taking part in a monetary union should aim at fiscal discipline, the Maastricht Treaty and the Stability and Growth Pact made provision for establishing a European governance framework for public finances, accompanied by binding fiscal rules. That framework is one of the cornerstones of Economic and Monetary Union, and it is vital that Member States comply with the rules for that union to work well (Melyn W. et al, 2015). It is not an easy thing to choose fiscal rules for the entire union, especially when there are such differences between economies, priorities and public needs between member states. But also, it is not impossible. Fiscal rules must accomplish some criteria in order to be applicable in all the countries. They have to be transparent so that everybody to be able to apply for them, they have to be flexible, to be adapted to every economic level and last but not least they have to be efficient and to determine best results together with other policies. For example, when it comes to taxes, labour market seems to be one of the most sensitive factor, because it affects all the contributors individually but the effects are visible at a large scale too, in all the economic environment. Radu et al. (2015) had an interesting point of view that the tax burden should be considered also indirect taxes, because it also exerts a high burden on individuals, and even if they are not subject to these taxes, they bear them.

At the macroeconomics level, two main fiscal rules mentioned in the Maastricht Treaty that have to be respected by all the member states in the European Union are the general government budget deficit, which is allowed to have a maximum level of 3\% of GDP and the general government debt ratio with a maximum level of $60 \%$ of GDP. It is very important to respect these rules in order to get to have a stable economic situation that is favorable to resist in front of different financial shocks.

Before the last crisis, the existing fiscal governance provisions had not prevented the buildup of fiscal imbalances. For example, the public debt-to-GDP ratio increased steadily from an average level of below 60 percent of GDP in 1991 to more than 70 percent of GDP in the late 1990s. Subsequently, a shallow reduction in the debt-to-GDP ratio during the 2000s reflected difficulties in building fiscal

24 DE GRUYTER OPEN
Studia Universitatis "Vasile Goldis" Arad. Economics Series Vol 26 Issue 3/2016 ISSN: 1584-2339; (online) ISSN: 2285 - 3065

Web: publicatii.uvvg.ro/index.php/studiaeconomia.Pages 18 - 32 
Vlad C., Ibadula B., Brezeanu P. (2016)

How taxes can contribute to the implementation of the public governance strategy? - An analysis for Eastern European Countries

sufficient buffers in good times, as unsustainable domestic demand booms generated higher revenues that were mistakenly assumed to be permanent. The buildup of imbalances also reflected the framework's inherent asymmetries, where ceilings are set on deficits in bad times without requiring surpluses in good times. When the crisis hit in 2008, EU member countries were ill-prepared. A severe economic downturn and large private-sector imbalances, which in part turned into public-sector liabilities, led to dramatic surges in debt ratios. This further strained fiscal rules, especially those that were set in nominal terms and did not foresee exceptional circumstances. Failure to build sufficient buffers in good times led to the need to tighten fiscal policies in bad times (Melyn W. et al, 2015) And to be able to do this, countries have to have a good public governance and a strong strategy. In order to cover or to decrease the accumulated public debt, countries needed an increase in public revenues through a higher fiscal pressure.

We wanted to see if the level of public debt influences the fiscal pressure, so we created an econometric model for three countries members of the European Union with similar economies. The model is based on a simple linear regression with the following formula:

$$
P=a+c * P D
$$

where $P$ - the total revenues from taxes and social contributions in million Euro, $P D$ - the total gross debt in million Euro, a and $\mathrm{c}$ - constants.

Regarding the period of time, we chose the lasts 13 years, $2002-2014$ in order to see the two variables that are correlated in an interval that includes an expansive economic situation, a crisis and a recovery period. The data used are representing annual values of total revenues from taxes and of the total gross debt for each analyzed country; it is important to mention that in the European Union, as a whole, during the crisis, a lot of member states had to borrow money in order to support the economy and the faster solution to recover the gap seems to be the increased fiscal revenues.

In Figure 1 we can see the results obtained for the Romania case. It can be noticed that through estimation, R-sqared and also the adjusted R-squared, have medium values, $51 \%$ and $47 \%$, which means that there is a correlation between the two fiscal indicators and the model demonstrates that the total revenues collected form taxes and social contributions are dependent on the total gross debt. Also the Durbin Watson test confirms this, with a value of 0.47 . The value of Prob (Fstatistic) obtained it is very low, less than $1 \%$, so not all the coefficients are nule (if we take into consideration a significance level tested at least $1 \%$ ), without referring to the constant coefficient, which confirms again that between the fiscal revenues and the public debt exists a direct linear connection. 
Vlad C., Ibadula B., Brezeanu P. (2016)

How taxes can contribute to the implementation of the public governance strategy? - An analysis for Eastern European Countries

Figure 1: The results obtained with the simple linear regression for Romania

\begin{tabular}{|c|c|c|c|c|}
\hline \multicolumn{2}{|c|}{ Dependent Variable: } & \multicolumn{3}{c|}{ Least Squares } \\
\hline \multicolumn{2}{|c|}{ Sethod: } & \multicolumn{3}{c|}{$2002-2014$} \\
\hline Included observations: & Coefficient & Std. Error & t-Statistic & Prob \\
\hline \hline Variable & $\mathbf{0 . 3 9 1 7 4 5}$ & $\mathbf{0 . 1 1 3 7 4 2}$ & $\mathbf{3 . 4 4 4 1 4 5}$ & $\mathbf{0 . 0 0 5 5}$ \\
\hline PD & $\mathbf{1 9 6 1 5 . 7 0}$ & $\mathbf{3 7 7 6 . 0 3 9}$ & $\mathbf{5 . 1 9 4 7 8 3}$ & $\mathbf{0 . 0 0 0 3}$ \\
\hline C & 0.518855 & \multicolumn{2}{|c|}{ Mean Dependent var } & 30567.15 \\
\hline \hline R-squared & 0.475115 & \multicolumn{2}{|c|}{ S.D. Dependent var } & 10135.55 \\
\hline Adjusted R-squared & 7343.106 & \multicolumn{2}{|c|}{ Akaike info criterion } & 20.78155 \\
\hline S.E. Of regression & $5.9 E+08$ & \multicolumn{2}{c|}{ Schwarz criterion } & 20.86846 \\
\hline Sum squared resid & -133.0801 & \multicolumn{2}{c|}{ F-statistic } & 11.86213 \\
\hline Log likelihood & 0.471211 & \multicolumn{2}{c|}{ Prob (F-statistic) } & 0.005484 \\
\hline Durbin-Watson stat & \multicolumn{3}{c}{}
\end{tabular}

Source: Eurostat data, own calculation

The idea that the public debt is correlated with fiscal policy is supported also by the representation from Figure 2, where we can see the evolution of the two indicators in Romania in the analyzed period.

Figure 2: The evolution of total revenues form taxes and social contributions $(P)$ and of total gross debt (PD) in Romania in 2002-2014

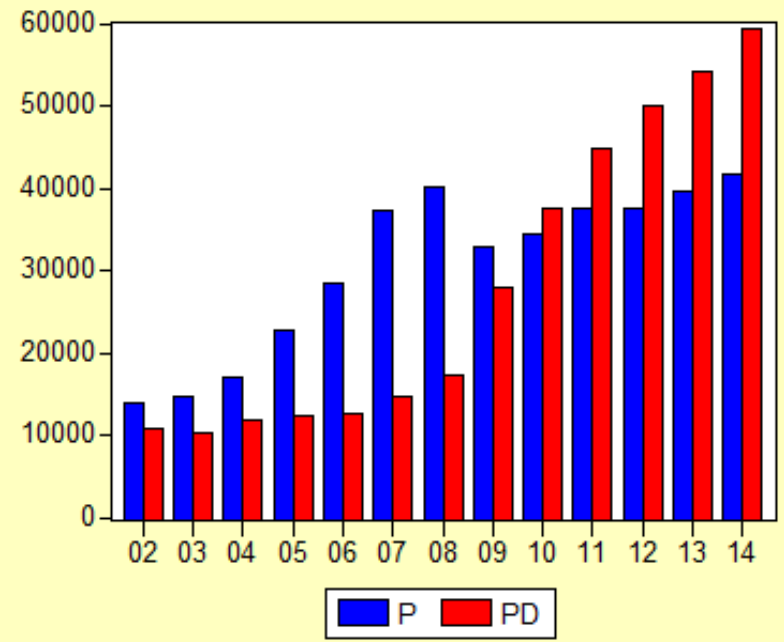

Source: Eurostat data, eviews representation 
Vlad C., Ibadula B., Brezeanu P. (2016)

How taxes can contribute to the implementation of the public governance strategy? - An analysis for Eastern European Countries

It can be easily observed that up to 2006, total revenues and total gross debts have constant and close values. Starting with 2006 until 2009, the total revenues from taxes increased a lot and the difference between them and the total gross debt was bigger and bigger. In other words, the collected amounts of money were higher than the borrowed ones. Once the crisis started to be felt, the total gross debt grew in 2009 and continued to grow every year, leaving behind the total revenues collected amounts.

The second country we wanted to analyze is Poland. We used the same series of data and we obtained a similar result, with a stronger correlation between variables if we compare to Romania. In Figure 3 you can observe the estimations, with results that confirm the connection between total gross debt and total revenues collected. R-squared and adjusted R-squared have bigger values than we saw in Romania's case, with $80 \%$ and $78 \%$. These percentages tell us that the model is a valid one.

Figure 3: The results obtained with the simple linear regression for Poland

\begin{tabular}{|c|c|c|c|c|}
\hline \multicolumn{2}{|c|}{ Dependent Variable: } & \multicolumn{3}{|c|}{$\mathrm{P}$} \\
\hline \multicolumn{2}{|c|}{ Method: } & \multicolumn{3}{|c|}{ Least Squares } \\
\hline \multicolumn{2}{|c|}{ Sample: } & \multicolumn{3}{|c|}{$2002-2014$} \\
\hline \multicolumn{2}{|c|}{ Included observations: } & \multicolumn{3}{|c|}{13} \\
\hline "Variable & Coefficient & Std. Error & t-Statistic & Prob \\
\hline PD & 0.470153 & 0.070047 & 6.71981 & 0.0000 \\
\hline $\mathbf{C}$ & 28685.20 & 11273.18 & 2.544 .552 & 0.0273 \\
\hline R-squared & 0.803749 & \multicolumn{2}{|c|}{ Mean Dependent var } & 101088.5 \\
\hline Adjusted R-squared & 0.785908 & \multicolumn{2}{|c|}{ S.D. Dependent var } & 25515.34 \\
\hline S.E. Of regression & 11805.97 & \multicolumn{2}{|c|}{ Akaike info criterion } & 21.73124 \\
\hline Sum squared resid & $1,53 \mathrm{E}+09$ & \multicolumn{2}{|c|}{ Schwarz criterion } & 21.81815 \\
\hline Log likelihood & -139.2530 & \multicolumn{2}{|c|}{ F-statistic } & 45.05069 \\
\hline Durbin-Watson stat & 1.617259 & \multicolumn{2}{|c|}{ Prob (F-statistic) } & 0.000033 \\
\hline
\end{tabular}

Source: Eurostat data, own calculation

In order to get to a truthful conclusion, below we have the same graph made for Poland. Here we can see that the variables have a different evolution in Poland compared to Romania. The constant trend up to 2006 and the growing one starting with 2009 is kept, but a visible difference we can notice: every year, in Poland the gross debt has higher values than the total revenues collected from taxes and social contributions. This means that the authorities borrowed more money than they could collect form their citizens. Of course, in 2008, the two variables have the closest values. 
Vlad C., Ibadula B., Brezeanu P. (2016)

How taxes can contribute to the implementation of the public governance strategy? - An analysis for Eastern European Countries

\section{Figure 4: The evolution of total revenues form taxes and social contributions $(P)$ and of total gross debt (PD) in Poland in 2002-2014}

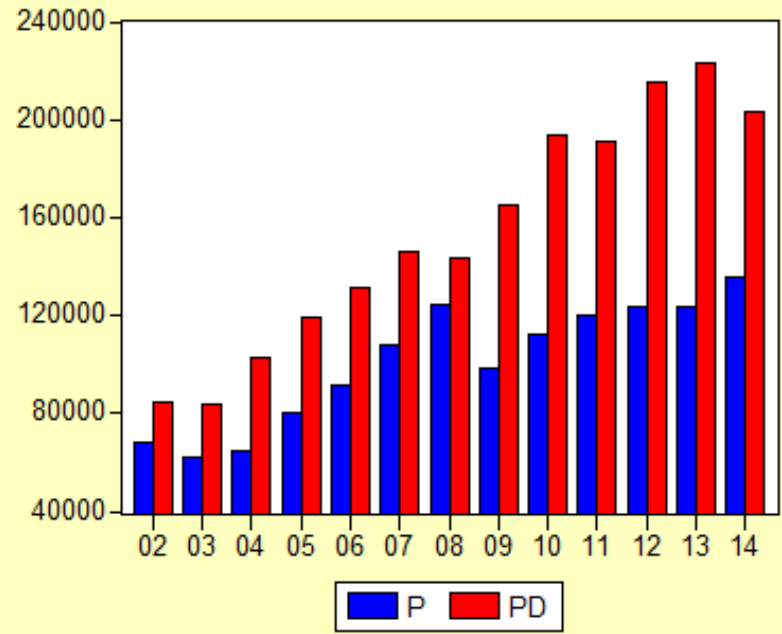

Source: Eurostat data, eviews representation

For the last estimation we chose Hungary as another Eastern European member state, where we will see that the results obtained have a lot in common with its neighbours.

Figure 5: The results obtained with the simple linear regression for Hungary

\begin{tabular}{|c|c|c|c|c|}
\hline \multicolumn{2}{|c|}{ Dependent Variable: } & \multicolumn{3}{|c|}{$\mathrm{P}$} \\
\hline \multicolumn{2}{|c|}{ Method: } & \multicolumn{3}{|c|}{ Least Squares } \\
\hline \multicolumn{2}{|c|}{ Sample: } & \multicolumn{3}{|c|}{$2002-2014$} \\
\hline \multicolumn{2}{|c|}{ Included observations: } & \multicolumn{3}{|c|}{13} \\
\hline Variable & Coefficient & Std. Error & t-Statistic & Prob \\
\hline PD & 0.299978 & 0.070047 & 6.138518 & 0.0001 \\
\hline $\mathbf{C}$ & 16127.63 & 3244.642 & 4.970541 & 0.0004 \\
\hline R-squared & 0.774041 & \multicolumn{2}{|c|}{ Mean Dependent var } & 35630.15 \\
\hline Adjusted R-squared & 0.753499 & \multicolumn{2}{|c|}{ S.D. Dependent var } & 4.783 .666 \\
\hline S.E. Of regression & 2375.035 & \multicolumn{2}{|c|}{ Akaike info criterion } & 18.52405 \\
\hline Sum squared resid & $6,20 \mathrm{E}+07$ & \multicolumn{2}{|c|}{ Schwarz criterion } & 18.61097 \\
\hline Log likelihood & -118.4063 & \multicolumn{2}{|c|}{ F-statistic } & 37.68141 \\
\hline Durbin-Watson stat & 1.490095 & \multicolumn{2}{|c|}{ Prob (F-statistic) } & 0.000073 \\
\hline
\end{tabular}

Source: Eurostat data, own calculation 
Vlad C., Ibadula B., Brezeanu P. (2016)

How taxes can contribute to the implementation of the public governance strategy? - An analysis for Eastern European Countries

Also in this case R-squared confirms the dependent relation between the debt and the taxes revenues with a strong percentage of $77 \%$. The value of Prob (F-statistic) obtained is less than $1 \%$, so not all the coefficients are nule (if we take into consideration a significance level tested at least $1 \%$ ), without referring to the constant coefficient, which leads us again to the conclusion that between the two variables exists a direct linear connection.

If earlier we saw that between Poland and Romania the evolution of total revenues and total gross debt is different at some point, we can observe below in Figure 6 that Hungary is different from both its neighbours. The gross debt is growing every year and the total revenues from taxes and social contribution has very low values if we sit them near the debt level, even before de crisis in 2002-2006 period. But despite this trend, the correlation still exists.

Figure 6: The evolution of total revenues form taxes and social contributions $(P)$ and of total gross debt (PD) in Poland in 2002-2014

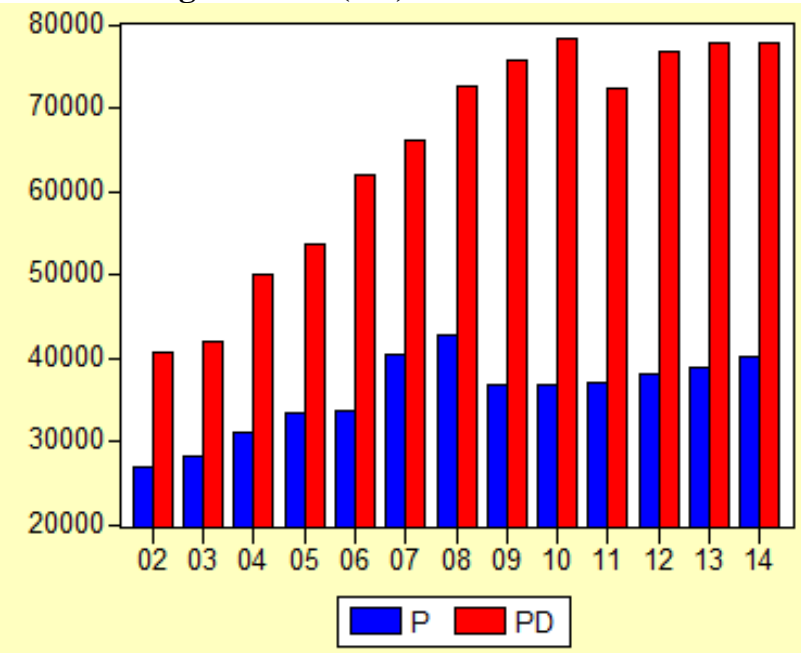

Source: Eurostat data, eviews representation

After analyzing the estimations for three countries from the European Union we can say that the results are close and similar, but not the same. This means that, as we sad in the beginning of this paper, the connection between total revenues and the total gross debt exists but in a different way for every country. 
Vlad C., Ibadula B., Brezeanu P. (2016)

How taxes can contribute to the implementation of the public governance strategy? - An analysis for Eastern European Countries

\section{CONCLUSION}

The analysis performed with this paper showed us that fiscal policies can contribute a lot in developing government strategy. The public governance in the European Union is seen in different perspectives and it has a major role in obtaining important economic goals for all the member states. And to get the expected results, they have to use a mix of multiple policies. We saw in the second section of this paper that the European Union is using different methods to lead the member states in the same direction and to impose rules and restrictions in order to protect them from economic shocks.

In the last section we developed an econometric model for three Eastern European countries: Romania, Poland and Hungary. We had chosen these three member states because they have similar economies and they joined the European Union at the same time. After we estimated the variables we saw that in all three cases the public debt, one of the main indicators regarding the public governance and fiscal pressure are connected; indeed the fiscal policy applied in a country is influenced by the level of public debt. When a country is increasing its debt, somehow, in one way, this surplus must be recovered; and one common way is to increase the budget revenues through fiscal revenues.

But at the same time, there were also some visible differences between the countries: the evolution of the total gross debt in comparison with the fiscal revenues. If in Romania up to 2010 every year the collected revenues are bigger than the gross debt, in Hungary and Poland the borrowed amounts are bigger than the collected ones in every year from our analyzed period. How can we translate this conclusion? It is better to keep the debt under control, until a crisis comes and forces you to borrow money in order to cover your costs and to increase the tax bases in order to pay your debt or a more favorable situation is to constantly borrow money and when the crisis comes maybe taxes can not be increased so much and the market won't face big changes regarding taxation? It is very hard to answer to this question, especially if we take into consideration that Poland was the single member state without an increased budget deficit in the crisis time. Maybe with another paper we will analyze a similar situation in the Western European area and we will see what kind of results we can obtain.

Also, with future research we intend to cover the limits of the current paper. We analyzed a short period of time and if we extend the data for sure we will be able to get to more clear conclusions and why not to answer to the question above. We were focused in this paper on the situation of three member states with similar economies, but the comparison with other member states with different economic approaches will represent an important goal for future papers. We will use in this

30 DE GRUYTER OPEN
Studia Universitatis "Vasile Goldis" Arad. Economics Series Vol 26 Issue 3/2016 ISSN: 1584-2339; (online) ISSN: 2285 - 3065

Web: publicatii.uvvg.ro/index.php/studiaeconomia.Pages 18 - 32 
Vlad C., Ibadula B., Brezeanu P. (2016)

How taxes can contribute to the implementation of the public governance strategy? - An analysis for Eastern European Countries

regard the World Governance indicators provided by World Bank, as a very good estimator for public governance.

Successive reforms have brought many positive elements to the framework and support the conduct of fiscal policy, but they have also increased its complexity. The current fiscal governance system involves an intricate set of constraints, which complicates effective monitoring and public communication, and creates risks of inconsistency and overlap between the different parts of the system (Michal A. et al, 2015). Therefore, sustainable fiscal policies to promote financial stability, economic growth in the euro area are required.

\section{REFERENCES}

1. Allard C. et al. (2013), Toward a Fiscal Union for the Euro Area, IMF, Staff Discussion Note, SDN/13/09, September 2013

2. Andrle M., Bluedorn J., Eyraud L., Kinda T., Koeva-Brooks P., Schwartz G., Weber A. (2015), Reforming Fiscal Governance in the European Union, International Monetary Fund Report, May 2015

3. Baldacci E., Petrova I., Belhocine N., Dobrescu G., Mazraani S. (2011), Assessing Fiscal Stress, IMF Working Paper

4. Besancon, M. (2003), Good Governance Rankings: The Art of Measurement. Cambridge, Mass.: Report for World Peace Foundation, Sept 2003

5. Brinkerhoff D.W., Brinkerhoff J.M. (2011), Public-privat partenership: Perspectives on purposes, publicness and good governance, RTI International (Research Triangle Institute), USA, George Washington University, USA

6. Caceres C., Kachanova A. (2012), Country Stress Events: Does Governance Matter?, IMF working paper, May 2012

7. Deutsche Bundesbank (2015), Approaches to Strengthening the Regulatory Framework of European Monetary Union, Monthly Report, March 2015 , 15-37

8. Dziemianowicz R. (2014), Independent Fiscal Institutions as a Tool of Fiscal Governance, Quarterly Journal of Economics and Economic Policy volume 9 issue 1, 2014 9. European Comission Report, Promoting good governance , 2014

10. Faure P. (2011), Public debt accumulation and institutional quality: can corruption improve welfare?, Ecnomics Bulletin, Volume 31, Issue 1, January 2011

11. Gradstein M. (2004), Governance and Growth, Journal of Development Economics

12. Graham J., Amos B., Plumptre T. (2003), Principles for Good Governance in the 21st Century Policy Brief No.15, Institute On Governance, Ontario, Canada

13. Gregor M., Comitted to deficit: the reverse side of fiscal governance, 2005

14. von Jürgen H. (1992), Budgeting procedures and fiscal performance in the European Communities, Economic Paper No. 96, Brussels

15. Istvan B. (2011), Rules-based economic governance in the European Union: A reappraisal of national fiscal rules, July 2011

16. Kaufmann D., Aart K., Massimo M. (2006), Growth and Governance: A Reply, The World Bank , Journal of Politics

Studia Universitatis "Vasile Goldis" Arad. Economics Series Vol 26 Issue 3/2016 ISSN: 1584-2339; (online) ISSN: 2285 - 3065

Web: publicatii.uvvg.ro/index.php/studiaeconomia.Pages $18-32$ 
Vlad C., Ibadula B., Brezeanu P. (2016)

How taxes can contribute to the implementation of the public governance strategy? - An analysis for Eastern European Countries

17. Mauro P. (2002), The Persistence of Corruption and Slow Economic Growth, IMF Working Paper

18. Manasse P., Roubini N., Schimmelpfennig A. (2003), Predicting Sovereign Debt Crises, IMF Working Paper

19. Melyn W., Van Meensel L., Van Parys S. (2015), European governance framework for public finances : presentation and evaluation, September 2015

20. Penev S. (2012), Economic and European Perspectives of Western Balkan Countries, Westminster Foundation for Democracy

21. Pere E. (2015), The impact of good governence in the economic development of Western Balkan Ccountries, European Journal of Government and Economics Volume 4, Number 1 (June 2015) ISSN: 2254-7088

22. Radu C.F., Dumiter F., Opret A.L. (2015), Labour taxation - a comparative study, Studia Universitatis „Vasile Goldis” Arad - Economics Series, Vol. 25, Issue 1/2015.

23. Sharma, D. Shalendra (2007), Democracy, Good Governance, and Economic Development, Taiwan Journal of Democracy

24. www.ec.europa.eu

25. www.imf.org

26. www.oecd.org 